\title{
Pesquisa bibliográfica no ambiente digital em medicina legal
}

\section{Bibliographical research in the digital environment in forensic medicine}

\author{
Suely Campos Cardoso', Valéria Vilhena1, Maria Fazanelli Crestana²
}

Cardoso SC, Lombardi V, Crestana MF. Pesquisa bibliográfica no ambiente digital em medicina legal. Saúde, Ética \& Justiça. 2004;9(1/2):33-7.

RESUMO: Através da Internet é possível realizar pesquisa bibliográfica em várias bases de dados gratuitas e algumas com acessos regulamentados nas Instituições de ensino e pesquisa. Este trabalho traz informações sobre as bases de dados: Medline, Embase, ISI, Lilacs, SciELO e informa títulos de periódicos de medicina legal que estão indexados nas bases Medline, Embase e JCR/ISI.

DESCRITORES: Acesso à informação, Bases de dados/utilização.

\section{INTRODUÇÃO}

O acesso aos recursos bibliográficos impressos e eletrônicos é essencial para os pesquisadores, acadêmicos e comunidades científicas que devem acompanhar a evolução de suas áreas de conhecimento, bem como divulgar seus achados científicos.

Os recursos digitais já estão incorporados aos hábitos de pesquisadores, que mesmo no ambiente da biblioteca tradicional fazem uso da tecnologia, como se refere Vilarino ${ }^{13}$ "... é o uso da biblioteca virtual - BV dentro da biblioteca tradicional” (p.25).

De acordo com Krzyzanowski e Ferreira ${ }^{\text {, " }}$ "a proliferação de títulos de periódicos nas diversas áreas do conhecimento tem sido preocupação dos profissionais que se interessam pela qualidade da informação científica, sejam autores, editores, publicadores, serviços de indexação, centros de documentação, bibliotecas e, especialmente, pesquisadores (usuários da informação)".

$\mathrm{Na}$ área de medicina legal, os primeiros periódicos científicos apareceram em 1821, na Alemanha, com a publicação "Zeitschrift für Staartzheikunde". Alguns anos mais tarde, surgiu a segunda revista "Anuals d'Hygiene Publique et de Medicine Légale" que foi criada por Orfila e Tardieu em $1829^{4}$.

Atualmente, através da Internet, é possível acessar, em alguns casos gratuitamente, inúmeros portais de pesquisa, bases de dados e web sites de instituições e de revistas científicas, que de acordo com Macedo e Modesto “ "... combina a recuperação da informação com recursos de hipertexto em um ambiente gráfico e multimídia" (p.59). Isso facilita ao pesquisador, que além de buscar documento para pesquisa deseja publicar e fazer uma análise do periódico científico ao qual deseja submeter seu artigo.

Vilarino $^{13}$ ao discorrer sobre dois fatores preponderantes para a utilização de recursos do mundo digital assegura que "é inevitável que lancemos mão das redes e das mídias digitais, pois elas nos trazem a informação em tempo real e atualizada, além de transporem as barreiras da localidade" (p.24).

Ao buscar um panorama da área de medicina legal, não se tem notícias de uma base de dados específica de medicina legal, e portanto devemos recorrer às bases de medicina, que trazem assuntos de medicina legal e áreas correlatas. Devem ser consideradas também as diversas nomenclaturas, tais

\footnotetext{
${ }^{1}$ Bibliotecárias, Serviço de Biblioteca e Documentação da Faculdade de Medicina da Universidade de São Paulo. ${ }^{2}$ Diretora Técnica, Serviço de Biblioteca e Documentação da Faculdade de Medicina da Universidade de São Paulo. Endereço para correspondência: Av. Dr. Arnaldo, 455-2 ${ }^{\circ}$ Andar, Sala 2308, CEP: 01246-903 São Paulo, SP. E-mail: suely@biblioteca.fm.usp.br
} 
como: legal medicine, forensic sciences, jurisprudence. As principais bases de dados na área de ciências da saúde são: Medline/Index Medicus, Embase/ Excerpta Medica, Web of Science/ISI, todas em inglês e para publicações latino-americanas existe o Lilacs.

Algumas dessas fontes de pesquisa são:

\section{a) Medline/Index Medicus}

O Medline ${ }^{10}$ é a base de dados mais importante na área de ciências da saúde, organizado pela National Library of Medicine, indexa aproximadamente
4.900 títulos de periódicos em Ciências da Saúde e Biomedicina publicados nos Estados Unidos e em mais de 90 países.

Essa base de dados engloba o Index Medicus, Index to Dental Literature, International Nursing Index. É uma publicação no idioma inglês, indexa os periódicos mais relevantes da área médica e os relaciona no List of Journals indexed for Medline ${ }^{8}$; os títulos de periódicos específicos em medicina legal estão indexados na categoria de Jurisprudência ${ }^{8}$, com um total de 58 títulos (Quadro 1).

Quadro 1. Periódicos sobre jurisprudência indexados na base de dados Medline e fatores de impacto - JCR/ISI ${ }^{8}$

\begin{tabular}{|c|c|}
\hline Título (Jurisprudence inclui: Forensic medicine and forensic psychiatry) & Fator de Impacto/JCR-2003 \\
\hline Acta Medicinae Legalis & - \\
\hline AIDS Policy \& Law & - \\
\hline American Journal of Forensic Medicine and Pathology & 0.527 \\
\hline American Journal of Law \& Medicine & 1.636 \\
\hline Annals of Health Law & - \\
\hline Archiv fur Kriminologie & - \\
\hline Behavioral Sciences \& the Law & 0.790 \\
\hline Canadian HIV/AIDS Polic Law Review/Canadian HIV/AIDS Legal Network & - \\
\hline Chicago School of Law, Institute for Health Law & - \\
\hline Cornell Law Review & 4.018 \\
\hline DePaul Journal of Health Care Law & - \\
\hline European Journal of Health Law & - \\
\hline Fa Yi Xue Za Zhi & - \\
\hline Food and Drug Law Journal & 0.404 \\
\hline Fordham Law Review & 0.836 \\
\hline Forensic Science International & 1.616 \\
\hline Health Care Law Monthly & - \\
\hline Health Law in Canada & - \\
\hline Health Law Journal & - \\
\hline Health Matrix & - \\
\hline HEC Forum: an Interdisciplinary Journal on Hospitals' Ethical and Legal Issues & - \\
\hline Hospital Law Newsletter & - \\
\hline International Journal of Law and Psychiatry & 0.795 \\
\hline International Journal of Legal Medicine & 2.093 \\
\hline Issues in Law \& Medicine & 0.400 \\
\hline JONA'S Healthcare Law, Ethics and Regulation & - \\
\hline Journal of Clinical Forensic Medicine & - \\
\hline The Journal of Contemporary Health Law and Policy & - \\
\hline The Journal of Forensic Odonto-Stomatology & - \\
\hline Journal of Forensic Sciences & 1.237 \\
\hline Journal of Health Law & - \\
\hline Journal of Health Politics, Policy and Law & 2.080 \\
\hline Journal of Law and Health & - \\
\hline Journal of Law and Medicine & - \\
\hline The Journal of Law, Medicine \& Ethics: a Journal of the American Society of Law, Medicine \& Ethics & 1.372 \\
\hline The Journal of Legal Medicine & 0.882 \\
\hline Journal of Nursing Law & - \\
\hline The Journal of Philosophy, Science \& Law [electronic resource] & - \\
\hline The Journal of Psychiatry \& Law & - \\
\hline The Journal of the American Academy of Psychiatry and the Law & - \\
\hline Law and Human Behavior & 1.556 \\
\hline Law and the Human Genome Review = Revista de Derecho y Genoma Humano / Chair in Law and the & \\
\hline Human Genome, BBV Foundation-Provincial Government of Biscay, University of Deusto & - \\
\hline Legal Medicine (Tokyo, Japan) & - \\
\hline Medical Law International & - \\
\hline Medicine and Law & - \\
\hline Medicine, Science, and the Law & 0.360 \\
\hline The Medico-Legal Journal & - \\
\hline Mental and Physical Disability Law Reporter & - \\
\hline Nippon Hoigaku Zasshi. The Japanese Journal of Legal Medicine & - \\
\hline Nursing Law’s Regan Report & - \\
\hline Population Reports. Series E, Law and Policy & - \\
\hline Science \& Justice: Journal of the Forensic Science Society & 0.791 \\
\hline SMU Law Review: a publication of Southern Methodist University School of Law & - \\
\hline Soudni Lekarstvi / Casopis Sekce Soudniho & - \\
\hline Lekarstvi Cs. Lekarske Spolecnosti J. Ev. International Journal of Neural Systems. Purkyne & - \\
\hline Specialty Law Digest. Health Care Law & - \\
\hline Sudebno-Meditsinskaia Ekspertiza & - \\
\hline Yale Journal of Health Policy, Law, and Ethics & - \\
\hline
\end{tabular}




\section{b) Web of Science do Institute for Scientific Information (ISI) 5}

O Web of Science é uma base de dados que permite a recuperação de trabalhos publicados nos mais importantes periódicos internacionais, apresentando as referências bibliográficas contidas nos mesmos, informando ainda, sobre os trabalhos que os citaram, com referências a outros trabalhos. Compreende o Science Citation Index, Social Citation Index e o Arts and Humanities Index 5 .

Pode ser pesquisada nos microcomputadores das instituições de ensino/pesquisa com acesso ao Portal Periódicos CAPES.

\section{c) Journal Citation Report do Institute for Scientific Information (ISI) ${ }^{5}$}

O JCR - Journal Citation Report é uma publicação anual do ISI, é uma importante ferramenta para os pesquisadores pois oferece recursos para a avaliação dos títulos de periódicos, como o fator de impacto do periódico, que informa a "média entre o número de artigos citados publicados nos dois anos anteriores ao ano corrente e o número total de artigos publicados nesses mesmos anos"12.

Quadro 2. Periódicos de medicina legal e criminologia no $\mathrm{JCR}^{5}$

\begin{tabular}{|c|c|}
\hline Títulos (Medicine, legal; Criminology and Penology) & Fator de impacto/2003 \\
\hline Aggression and Violent Behavior & 1.143 \\
\hline American Journal of Forensic Medicine and & \\
\hline Pathology & 0.527 \\
\hline Australian and New Zeland Journal of Criminology & 0.205 \\
\hline British Journal of Criminology & 0.735 \\
\hline Canadian Journal of Criminology & 0.323 \\
\hline Crime \& Delinquency & 0.786 \\
\hline Crime and Justice - A Review of Research & 0.923 \\
\hline Crime Law and Social Change & 0.275 \\
\hline Criminal Justice and Behavior & 1.754 \\
\hline Criminal Law Review & 0.203 \\
\hline Criminology & 2.424 \\
\hline Expert Opinion on Therapeutic Patents & 1.642 \\
\hline Federal Probation & 0.143 \\
\hline Forensic Science International & 1.616 \\
\hline International Journal of Legal Medicine & 2.093 \\
\hline International Journal of Offender Therapy and & \\
\hline Comparative Criminology & 0.420 \\
\hline Journal of Criminal Justice & 0.484 \\
\hline Journal of Criminal Law \& Criminology & 0.775 \\
\hline Journal of Forensic Psychiatry \& Psichology & 0.530 \\
\hline Journal of Forensic Sciences & 1.237 \\
\hline Journal of Interpersonal Violence & 0.820 \\
\hline Journal of Law Medicine and Ethics & 1.372 \\
\hline Journal of Quantitative Criminology & 0.917 \\
\hline Journal of Research in Crime and Delinquency & 2.061 \\
\hline Justice Quarterly & 0.961 \\
\hline Kriminalistik & 0.139 \\
\hline Medicine Science and Law & 0.360 \\
\hline Policing & 0.141 \\
\hline Psychology Crime \& Law & 0.486 \\
\hline Regulatory Toxicology and Pharmacology & 1.440 \\
\hline Science \& Justice & 0.791 \\
\hline Social \& Legal Studies & 0.263 \\
\hline Theoretical Criminology & 0.919 \\
\hline
\end{tabular}

\section{d) Embase/Excerpta Medica}

$\mathrm{EMBASE}^{3}$, é uma base de dados que dá ênfase aos títulos de periódicos publicados na Europa.

É a versão eletrônica das 52 seções da Excerpta Medica, com registro bibliográfico desde 1974. A Excerpta Medica tem uma seção específica na área de medicina legal, a de $n^{\circ} 49$ (Excerpta Medica: Section 49, Forensic Science Abstracts).

Quadro 3. Periódicos na área de medicina legal indexados na Embase/Excerpta Medica

\begin{tabular}{|l|c|}
\hline Títulos (Forensic science) & Fator de impacto/ \\
& 2003 \\
\hline Adli Tip Dergisi (Istanbul) & - \\
American Journal of Forensic Medicine and & \\
Pathology (NY) & 0.527 \\
American Journal of Law and Medicine & 1.636 \\
Archiv Fur Kriminologie & - \\
Behavioral Sciences and the Law & 0.790 \\
Beitrage Zur Gerichtlichen Medizin & - \\
Blutalkohol & - \\
Child Abuse and Neglect & 0.977 \\
Criminal Behaviour and Mental Health & - \\
Death Studies & 0.614 \\
Forensic Science International & 1.616 \\
International Journal of Law and Psychiatry & 0.795 \\
International Journal of Legal Medicine & 2.093 \\
Journal of the Canadian Society of Forensic Science & - \\
Journal of Child Sexual Abuse & - \\
Journal of Drug Issues & 0.743 \\
Journal of Forensic Odonto-Stomatology & - \\
Journal of Forensic Sciences & 1.237 \\
Journal of the Forensic Science Society & - \\
Journal of the Indian Academy Forensic Sciences & - \\
Journal of Legal Medicine & - \\
Journal of Medical Ethics & - \\
Journal de Medicine Legale Droit Medical & - \\
Journal of Psychiatry and Law & - \\
Journal of Research in Crime and Delinquency & -.360 \\
Journal of Studies on Alcohol & - \\
Journal of Traffic Medicine & - \\
Japanese Journal of Forensic Toxicology & - \\
Japanese Journal of Legal Medicine & - \\
Law and Human Behavior & - \\
Medicine and Law & - \\
Medicine Science and the Law & - \\
Police Surgeon & - \\
Sudebno-Meditsinskaya Ekspertisa & \\
Suicide and Life-Threatening Behavior & - \\
Violence and Victims & - \\
Zacchia & - \\
\hline
\end{tabular}

\section{e) LILACS - Literatura Latino-americanca e do} Caribe em Ciências da Saúde ${ }^{7}$

Coordenadada pela BIREME - Centro Latinoamericano e do Caribe em Ciências da Saúde, é produzida de forma cooperativa pelas instituições que integram o Sistema Latinoamericano e do Caribe de Informação em Ciências da Saúde desde 1982. Para 
a indexação e recuperação do conhecimento científico produzido utiliza o DECs - Descritores em Ciências da Saúde, uma versão do MESH - Medical Subject Headings, do Medline. Utiliza termos em inglês, português ou espanhol, para pesquisa bibliográfica de documentos como: artigos de periódicos, livros, capítulos de livros, anais de congressos, informes técnicos-científicos, publicações governamentais².

\section{f) SciELO - Scientific Eletronic Library Online ${ }^{11}$}

Iniciado pela parceria FAPESP - Fundação de Amparo a Pesquisa no Estado de São Paulo e BIREME, sendo que, a partir de 2002 recebe o apoio do CNPq (Conselho Nacional de Pesquisa).

É uma biblioteca eletrônica que abrange uma coleção selecionada de periódicos científicos brasileiros e latino-americanos. "Tem por objetivo desenvolver metodologia comum para a preparação, armazenamento, disseminação e avaliação da produção científica em formato eletrônico" 11 .

Proporciona acesso à sua coleção de periódicos através de uma lista alfabética de títulos, ou por meio de uma lista de assuntos, ou ainda através de um módulo de pesquisa de títulos dos periódicos, por assunto, pelos nomes das instituições publicadoras e pelo local de publicação.

\section{CONSIDERAÇÕES FINAIS}

A importância do acesso eletrônico e das bases de dados na pesquisa bibliográfica pode ser notada nas principais mudanças ocorridas no contexto da identificação e busca de documentos científicos. $\mathrm{O}$ acesso remoto aos documentos e a disponibilização eletrônica dos mesmos, significa para pesquisadores, acadêmicos e profissionais da informação um salto de qualidade, não só no tempo dispendido nestas tarefas, como para a relevância e objetividade de análise do material recuperado.

Resumido por Aquino" como: "... um movimento sociocultural de superação da invenção do computador pessoal que instaurou um desenvolvimento tecnoeconomico sem precedentes na história do conhecimento e da informação" (p.10).

As possibilidades de pesquisa de suas ferramentas, oferecidas pelas bases de dados, como interfaces amigáveis, downloands, estratégias de busca, rapidez de recuperação e acessos aos textos completos têm mudado o paradigma da pesquisa bibliográfica, principalmente em função dos ambientes virtuais.

Nesse contexto, tanto profissionais que trabalham na entrada dos registros e documentos, como aqueles que têm interesse na entrega ou recuperação dessas informações, segundo Zaher ${ }^{14}$ " "... necessitam conhecer e trabalhar com os sistemas de identificação e descrição de objetos digitais, inclusive sua localização no espaço cibernético" (p.685).

Cardoso SC, Vilhena V, Crestana MF. Bibliographical research in the digital environment in forensic medicine. Saúde, Ética \& Justiça. 2004;9(1/2):33-7.

ABSTRACT: Now a days it is possible to make bibliographical research throught the Internet in some databases, that are gratuitously and also some with accesses regulated in the Institutions of education and research. This work brings information on the databases: Medline, Embase, ISI, Lilacs, SciELO. It informs periodic headings of forensic medicine that are indexed in the Medline, Embase and JCR/ISI.

KEY WORDS: Access to information, Databases/utilization.

\section{REFERÊNCIAS}

1. Aquino MA. Metamorfoses da cultura: do impresso ao digital, criando novos formatos e papéis em ambientes de informação. Ci Inf [Brasília]. 2004;33(2):7-14.

2. Armenteros Vera I. Procedimientos de trabajo para LILACS. ACIMED. 2002;10(4):7-8.

3. Embase. Disponível em: http://www.embase.com

4. França GV. Medicina legal. Rio de Janeiro: Guanabara Koogan; 2000.
5. ISI - Institute Scientific Information. Web of science and journal citation report. Disponível em: http:// isi02.isiknowledge.com/portal.cgi/

6. Krzyzanowski RF, Ferreira MCG. Avaliação de periódicos científicos e técnicos brasileiros. Ci Inf [Brasília]. 1998;27(2).

7. LILACS. Disponível em: http://www.bireme.br.

8. List of journals indexed in Medline. Bethesda: NLM; 2004. 
Cardoso SC, Vilhena V, Crestana MF. Pesquisa bibliográfica no ambiente digital em medicina legal.

9. Macedo ND de, Modesto F. Equivalências: do serviço de referência convencional a novos ambientes de redes digitais em bibliotecas. Rev Bras Bibliotecon Doc [São Paulo]. 1999;1(1):55-72.

10. Medline (PubMed - National Library of Medicine). Disponível em: http://www.ncbi.nlm.nih.gov/entrez/ query.fcgi? DB=pubmed.

11. SciELO - Scientific Eletronic Library Online. Disponível em: http://www.scielo.br.

12. Universidade de São Paulo. Sistema Integrado de Bibliotecas. Grupo de Estudos de Usuários da
Informação. Web of science. Journal citation report. Informações preliminares aos usuários. São Paulo: SIBi/USP; 1998.

13. Vilarino EG. Surgimento, implantação e gestão de bibliotecas virtuais: uma revisão de literatura. Perspect Cienc Inf [Belo Horizonte]. 2003;8(1):12-27.

14. Zaher CR. Capturando no espaço cibernético: a aquisição sem fronteiras. In: Integrar: $1^{\circ}$ Congresso Internacional de Arquivos, Bibliotecas, Centros de Documentação e Museus. Textos. São Paulo: IMESP; 2002. p.673-90. 